A Journal of Agricultural Science Published by the California Agricultural Experiment Station

CONTENTS

ONTOGENY AND STRUCTURE OF THE PHLOEM OF TOBACCO

KATHERINE ESAU

\title{
THE MULTINUCLEATE CONDITION IN FIBERS OF TOBACCO
}

KATHERINE ESAU

\section{MORPHOLOGICAL DEVELOPMENT OF THE FRUIT OF THE OLIVE}

J. R. KING 


\section{THE MULTINUCLEATE CONDITION IN FIBERS OF TOBACCO}

KATHERINE ESAU 



\title{
THE MULTINUCLEATE CONDITION IN FIBERS OF TOBACCO
}

\author{
KATHERINE ESAU ${ }^{2}$
}

\section{INTRODUCTION}

THE OCCURRENCE of a multinucleate phase in the development of fibers, although rarely mentioned in literature, is a known fact (Eames and MacDaniels, 1925, p. 56). It was apparently established by Treub (1880), who reported that phloem fibers are multinucleate in many angiosperms and that this condition results from division of nuclei without subsequent formation of cell plates.

The multinucleate fibers of tobacco were noted in connection with certain investigations on the phloem of this genus (Esau, 1938). A somewhat detailed study of these fibers seemed of interest, because occasionally writers report multinucleate condition in healthy or diseased cells without giving convincing evidence to support their contention.

The fibers of tobacco were studied in stems and leaves of Nicotiana tabacum L. and Nicotiana glauca Graham. As in the previous work (Esau, 1938) the material was killed in chrom-acetic-formalin solution and was imbedded in paraffin after a dehydration in butyl- and ethylalcohol mixtures. The illustrations were prepared from slides stained following Heidenhain's schedule.

\section{RESULTS}

As was shown in the paper on phloem of tobacco (Esau, 1938), the multinucleate fibers of this genus arise from procambium among primary sieve tubes and are, therefore, interpreted as primary phloem fibers. These elements occur in the internal as well as external phloem and differentiate in the elongating portion of the stem or leaf.

During the elongation of the fibers their nuclei divide mitotically (plate 2, A), with splitting of chromosomes and formation of normal daughter nuclei. The karyokinesis is not, however, followed by cytokinesis. In the ordinary cell division the cell plate becomes clearly evident before the daughter nuclei emerge from the telophase (plate $1, A$ ), whereas in the fibers no cell plate is developed (plates $1, B ; 2, B$ and $C$ ). The spindle fibers are less persistent than in ordinary division figures and gradually disappear during late anaphase and telophase (plates $1, B$ and $2, C$ ).

\footnotetext{
${ }^{1}$ Received for publication March 10, 1938.

${ }^{2}$ Assistant Botanist in the Experiment Station.
} 
The two daughter nuclei pass into a resting stage (plate $1, D$ ) for a more or less prolonged period and then divide again, both at the same time (plate $2, E$ and $F$ ). As a result of this division, four nuclei appear in the same cell (plates $1, E$ and 2, $G$ ).

Very frequently the four nuclei divide again. These divisions also take place simultaneously in all nuclei of the same cell (plate $2, I$ ) and give rise to eight normal nuclei (plate $2, J$ ).

The multinucleate condition is evident in longitudinal (plates $1, D$ and $E ; 2, G$ and $J$ ), in radial and tangential, and occasionally in transverse sections (plate $1, C$ ). If the nuclei are arranged in a longitudinal row within the cell (plate $2, G$ and $J$ ), only one nucleus will be evident in a transverse section. But sometimes nuclei slightly overlap within the row or even occur in clumps (plate $2, H$ ); in such instances transverse sections might include more than one nucleus.

The clumping of nuclei usually occurs in cells that already have secondary wall thickenings (plate $2, H$ ).

Fibers in advanced stages of development often show lobed nuclei derived, apparently, from fusion of two or more nuclei. In almost mature fibers with fully developed secondary walls the nuclear material frequently occurs as one large degenerating mass. Occasional lobing of this mass seems to indicate that it has been derived from fused nuclei. Individual degenerating nuclei have also been observed.

Since multinucleate cambium cells are occasionally reported in literature, the nuclear phenomena in fibers of tobacco were compared with those in the cambium of the same plant.

Two or more nuclei that appear to lie in the same cell are frequently noted in fusiform initials in tangential sections of tobacco cambium (plate 2, D). Careful examination may reveal, however, a break in the cytoplasmic layer between the two nuclei (plate $1, F$ ). The radial walls may or may not appear discontinuous. In the cells shown in plate $1, F$, the wall to the right of the nuclei seemed continuous, but the one to the left was slightly thinner in the region where the protoplasts showed a break.

The apparent multinucleate condition of cambium cells may be observed only in tangential longitudinal sections, not in radial or transverse ones.

As Bailey (1920b) has already explained, cambium cells may appear multinucleate because the radially flattened fusiform initials are exactly superimposed in radial direction and the nuclei of two or more initials occur very near the same focal plane. No tangential section, moreover, succeeds in being perfectly parallel to a fusiform initial; if cut on slant, it may easily show two or even more nuclei in almost exactly 
the same focal plane (plates $1, F$ and $2, D$ ). If one of these two nuclei is covered by a portion of the tangential wall that divides the two radially adjacent fusiform initials, the sharpness of definition of the nucleus is not impaired, because the wall is very thin. A similar condition is observed in polar views of dividing cells wherein the two daughter nucleione lying above, the other beneath, the incomplete cell plate-appear equally sharply differentiated when each is brought into focus. The cell plate, being thin, hardly interferes with passage of the light; but the kinoplasmosomes on the margins of the growing cell plate (plate 1, $G$ ) serve as a proof of its presence (Bailey, 1919, 1920a, 1920b).

\section{DISCUSSION}

A review of literature on multinucleate cells is beyond the scope of this paper. Suffice it to point out that nuclear phenomena characteristic of tobacco fibers are comparable with those observed by other workers in certain elongated cells of the vegetative organs. The origin of multinucleate condition through omission of cytokinesis occurs, for example, in phloem fibers and in certain latex cells of many angiosperms (Treub, 1880) ; and in vessel mother cells of Dioscoreaceae and Euphorbiaceae, including the genus Ricinus (Pirotta and Buscalioni, 1898; Smolák, 1904 ; Němec, 1910). The references given above also indicate that simultaneous division of nuclei of one cell is a common phenomenon. Smolák (1904) and Němec (1910), describing clumping and fusion of nuclei, remark that partly fused nuclei may appear as though dividing amitotically. Küster (1935, p. 148-49) thinks that clumping of nuclei indicates approaching nuclear fusion, either normal or pathological.

Certain conditions frequently lead to misconceptions concerning numbers of nuclei in cells.

A comparison of views of multinucleate fibers (plates $1, D$, and 2, $G$ ) with tangential sections of fusiform initials (plates $1, F$ and 2, $D$ ) shows how easily the latter may be taken for multinucleate elements. Bailey $(1920 b)$, discussing papers that describe multinucleate cambium cells, gives comprehensive data to prove that ray and fusiform initials are uninucleate in gymnosperms and angiosperms.

Sometimes, through inability to recognize stages of cytokinesis, workers interpret ordinary somatic cells as multinucleate. Bailey (1920c), Goldstein (1925), and Wareham (1936), reviewing several papers describing multinucleate cells in young tissues of stems, furnish convincing evidence that the authors of these papers were in error.

A more recent questionable interpretation of cytokinesis leading to an identification of cells as binucleate is found in a paper by Artschwager and Starrett (1936). Their plate 7 gives the photographs showing in- 
complete cell plates in sectional views as illustrations of normal division (plate 7, $A$ and $C$ ). Where, however, the cell plate appears in face view, with its kinoplasmosomes forming either a halo or two separate aggregations (fig. 7, $B, D-H$ ), the division is interpreted as abnormal-that is, as a nuclear division not accompanied by cell-plate formation. In view of Bailey's (1919, 1920a, 1920b, 1920c), Goldstein's (1925), and Wareham's (1936) papers, all the division figures given by Artschwager and Starrett, plate 7, appear normal.

\section{SUMMARY}

The fibers of the primary external and internal phloem of Nicotiana tabacum L. and $N$. glauca Graham show a multinucleate condition resulting from repeated nuclear divisions with omission of cytokinesis.

\section{ACKNOWLEDGMENT}

The writer is grateful to Mr. A. W. Skuderna of the American Beet Seed Company, Rocky Ford, Colorado, for translating Smolák's article from the Czech. 


\section{LITERATURE CITED}

Art'schwager, E., and R. C. StarketT.

1936. Histological and eytological ehanges in sugar-beet seedlings affected with curly top. Jour. Agr. Research 53:637-57.

BAILEY, I. W.

1919. Phenomena of cell division in the cambium of arborescent gymnosperms and their cytological significance. National Acad. Sci. Proc. 5:283-85.

$1920 a$. The formation of the cell plate in the cambium of the higher plants. National Acad. Sci. Proc. 6:197-200.

$1920 \mathrm{~b}$. The cambium and its derivative tissues. III. A reconnaissance of cytological phenomena in the cambium. Amer. Jour. Bot. 7:417-34.

1920c. Phragmospheres and binucleate cells. Bot. Gaz. 70:469-71.

Eames, A. J., and L. H. MacDaniels.

1925. An introduction to plant anatomy. 364 p. MeGraw-Hill Book Co., New York, N. Y.

Esau, Katherine.

1938. Ontogeny and structure of the phloem of tobacco. Hilgardia 11(8):343-424.

Goldstein, Bessie.

1925. A study of progressive cell plate formation. Bul. Torrey Bot. Club 52: 197-219.

KüSTER, ERNST.

1935. Die Pflanzenzelle. 672 p. Gustav Fischer, Jena.

NĚMEC, B.

1910. Das Problem der Befruchtungsvorgänge und andere zytologische Fragen. 532 p. Gebrüder Borntraeger, Berlin.

Pirotta, R., and L. Buscalioni.

1898. Sulla presenza di elementi vascolari multinucleati nelle Dioscoreaceae. Ann. R. Ist. Bot. Roma 7:237-54.

SMOLÁk, JaRosLAV.

1904. O mnohojaderných bunkách Euphorbiacei. (On multinucleate cells of Euphorbiaceae.) Rozpr. České Akad. Cís. Františka Josefa (Ann. Czech Akad. Emp. Franz Joseph) Sec. II Math.-Biol. 13:1-14.

Treub, M.

1880. Sur les cellules végétales a plusieurs noyaux. Arch. Neerland. Sci. Exact. et Nat. 15:39-60.

WAREHAM, R. T.

1936. "Phragmospheres" and the "multinucleate phase" in stem development. Amer. Jour. Bot. 23:591-97. 


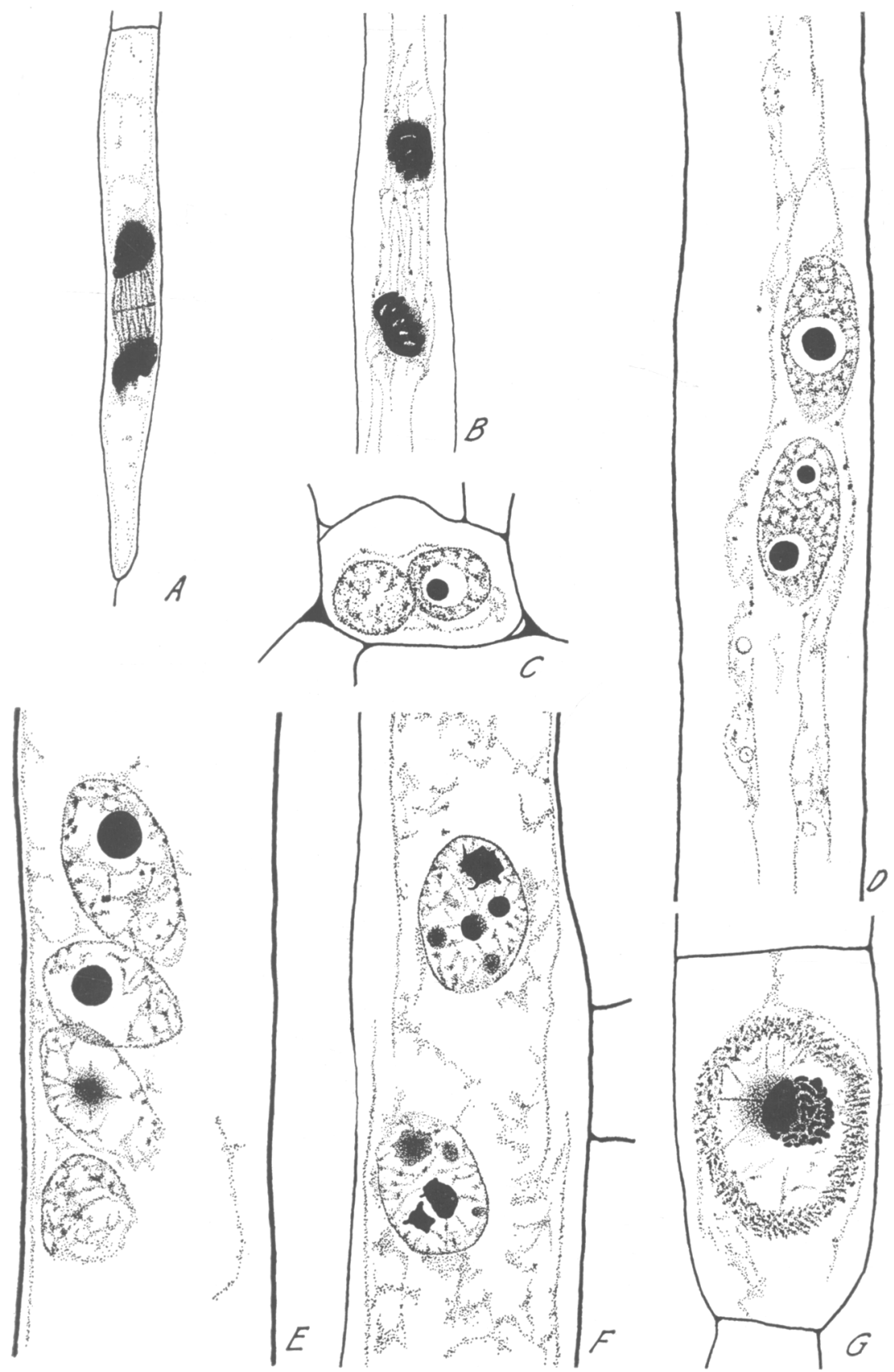

Plate 1-A Transversely dividing procambium cell with an evident cell plate between daughter nuclei. $B$, Nuclear division in a young fiber; no cell plate is formed. $C$, Transverse, and $D$ and $E$, longitudinal sections of multinucleate fibers. $F$, Apparent binucleate condition in fusiform initials in a tangential section. $G$, Ray cell in division showing, in face view, an incomplete cell plate with a halo of kinoplasmosomes. (All $\times 1035$.) 
HILGARDIA, VOL. 11, NO. 8
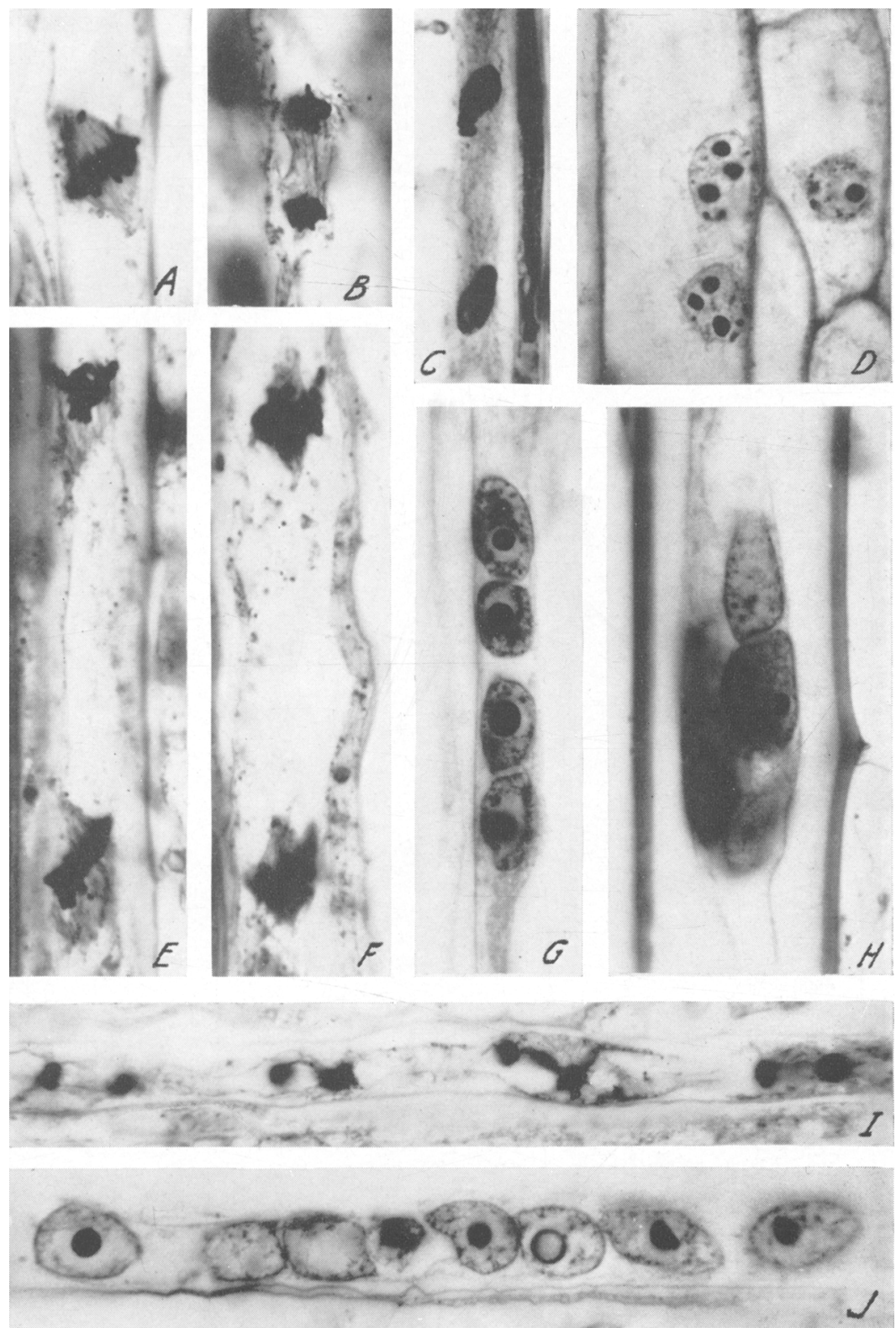

Plate 2.-A-C, E, $F, I$, Divisions of nuclei in multinucleate fibers; $E$ and $F$ are two sections of the same cell. $D$, Apparent binucleate condition in the cambium. $G, J$, Nuclei of fibers in resting stage. $H$, Clump of nuclei in a fiber with secondary wall thickening. $($ All $\times 810$. 